\title{
ON THE DEPOSITION OF SUBGLACIAL AND MELT-OUT TILLS AT THE MARGINS OF CERTAIN SVALBARD GLACIERS
}

\author{
By G. S. Boulton \\ (School of Environmental Sciences, University of East Anglia, Norwich, England)
}

Abstract. Two types of basal till are described. First, melt-out tills released by the melting of masses of buried, debris-rich stagnant ice. Top melting of these ice masses is of greatest importance at the present day, and this produces tills which retain some of their englacial fabrics although some are changed by the melting process. Bottom melting of these masses could also produce such tills but these are likely to be much less important. Secondly, tills are also formed subglacially when basal debris-rich glacier ice becomes stationary beneath the over-riding active glacier. When these subglacial masses melt, water is expelled from the resultant till which also shows tectonic shear fractures induced by the over-riding ice. The mode of deposition of these latter tills could also be responsible for the production of certain rock-cored drumlins. Subglacial tills in Svalbard are relatively rare and, except under special conditions, are likely to react to

If a basal freezing hypothesis is accepted for the origin of most englacial debris, the lateral and vertical variations in erratic content can be predicted for many melt-out tills.

RÉsumé. Sur le dépot de moraines de fond (tills), sous glaciaires et de fusion, sur les marges de certains glaciers du Svalbard. Deux types de till sont décrits. Premièrement les tills résultant de l'écoulement des eaux de fusion de glaces stagnantes enterrées sous de grandes quantités de matériaux rocheux. La fonte superficielle de ces masses de glace est de plus grande importance à l'heure actuelle; elle donne naissance à des tills qui conservent certains faciès "glaciaires" tandis que d'autres sont modifiés par le pro essus de fonte. La fusion basale de ces masses peut aussi donner de tels tills mais ceux-ci sont probablement moins importants. Deuxièmement les tills sont également d'origine sous glaciaire quand la partie inférieure du glacier riche en inclusions rocheuses devient stationnaire sous le glacier actif qui la chevauche. Quand ces masses sous glaciaires fondent, l'eau est expulsée du till résultant qui montre également des fractures tectoniques de tension dues au chevauchement de la glace. Le mode de dépot de ces derniers tills peut être à l'origine de certains drumlins à coeur "rocheux". Les tills sous glaciaires sont rares au Svalbard et excepté sous certaines conditions particulières sont probablement conditionnées davantage par la surchage de glace qui provoque l'éssorage des dépots, leur compaction, les fractures de tension qui les affectent que par l'écoulement liquide.

Si l'hypothèse de gel basal est retenue pour expliquer l'origine de la plupart des matériaux enchassés dans la glace les variations en largeur et en épaisseur du volume du contenu "erratique" peuvent être prévues
pour de nombreux tills "de fusions".

Zusammenfassung. Zur Ablagerung von subglazialen und ausgeschmolzenen Moränen am Rande bestimmter Gletscher in Svalbard. Zwei Arten von glazialen Ablagerungen werden beschrieben. Erstens Ausschmelzablagerungen, die durch das Abschmelzen von bedecktem, schuttreichem und stagnierendem Eis freigegeben werden. Die Abschmelzung dieser Eismassen von oben her ist in der Gegenwart von grösster Bedeutung: sie hinterlässt Ablagerungen, die ihr intraglaziales Gefüge teilweise beibehalten, teilweise wird es jedoch durch Ablagerungen entsteherändert. Durch das Schmelzen am Grunde dieser Massen könnten ebenfalls solche auch subglazial, wenn grundschuttreiches weit weniger wichtig sind. Zweitens bilden sich Ablagerungen Gletscher stationär wird. Beim Schmelzen dietschereis unter dem darüberhinwegfliessenden aktiven Gletscher stationär wird. Beim Schmelzen dieser subglazialen Massen tritt Schmelzwasser aus den entstehenden Ablagerungen aus; sie zeigen auch tektonische Scherbrüche, hervorgerufen durch das darüberbewegte bestimmter Drumlins mit Felskernen sein. Subglaziale Ablagerungen sind in Svalbard verhältnismässig
bestengenten die Entstehung selten; vermutlich reagieren sie-ausser unter besonderen Bedingungen - auf Eisbelastungen eher mit Wasseraustritt, Verdichtung und Scherbrüchen als mit Fliessbewegungen.

Wird die Herkunft intraglazialen Schuttes vor allem auf Gefriervorgänge am Untergrund zurückgeführt, so kann die seitliche und vertikale Verteilung des Schuttgehaltes für viele Ausschmelzablagerungen voraus-
gesagt werden.

\section{INTRODUCTION}

In a previous paper (Boulton, I970), it was argued that the major part of the subglacially derived debris transported by Svalbard glaciers is carried in an englacial position. It was further argued that much of this debris is incorporated by a process of basal freezing and it was tentatively suggested that the transport of such great volumes of englacial debris is a characteristic of certain types of cold polar rather than temperate glacier. 
In certain circumstances (Boulton, 1968) much of this transported debris is deposited supraglacially as flow till as a result of lowering of the glacier surface by ablation. This debris can also be deposited from masses of debris-rich stagnant ice buried beneath a sediment overburden, or beneath the sole of an active glacier.

The locations of glaciers referred to in the text are shown in Figure $\mathrm{I}$.

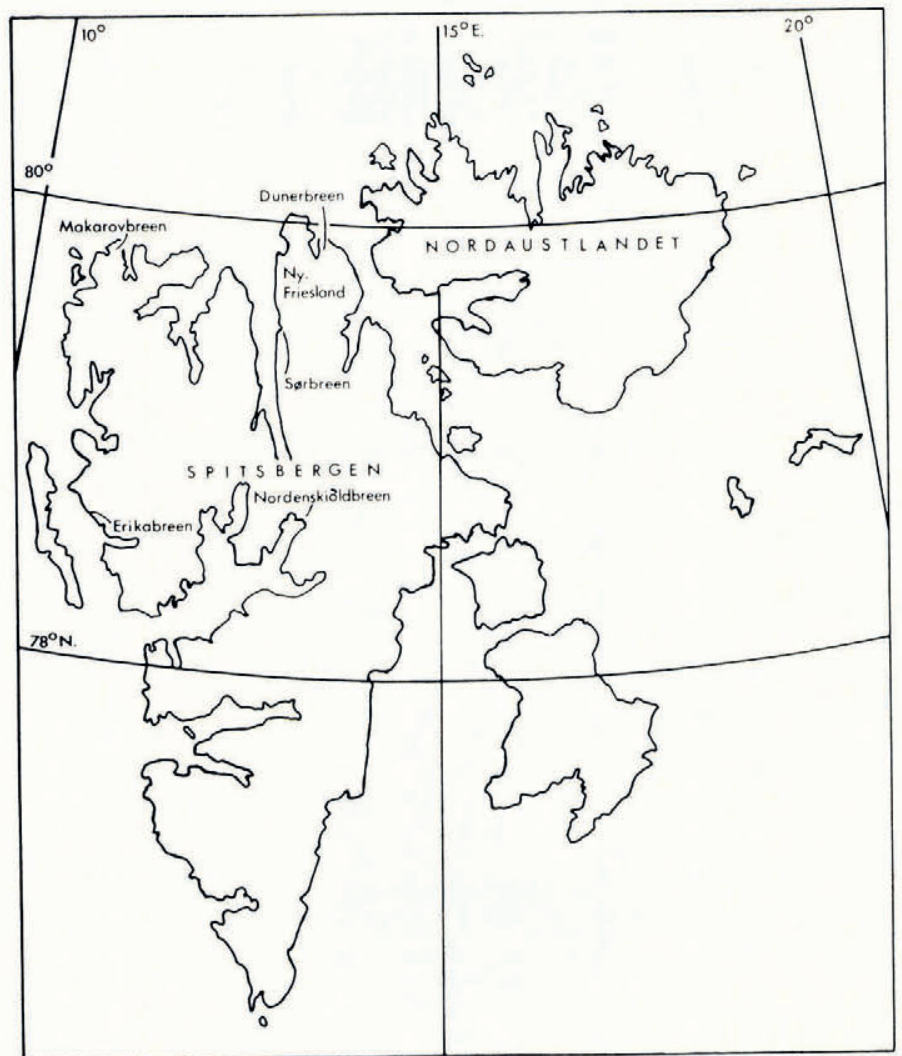

Fig. 1. Map of part of Svalbard, showing the locations of glaciers referred to in the text.

\section{Deposition of MELT-OUT TILLS FROM BURIED STAGNANT ICE MASSES}

Beyond the active margins of many glaciers in Svalbard there are broad areas of glacial deposits, tills and outwash, which are underlain by stagnant glacier ice masses of considerable thickness. This ice is preserved during retreat of the active ice front by the extrusion of flow till upon it (Boulton, I968) and supraglacial deposition of fluvial and lacustrine outwash sediments, both of which inhibit its ablation and produce hummocky ice-cored kame and moraine landscape.

The masses of buried stagnant ice represent the basal zones of the glacier and thus commonly contain a great deal of debris. For instance, the till-covered dead ice in the terminal moraine of Dunerbreen (Boulton, i968, fig. 3a) contains sufficient debris to give rise to a till at least $5 \mathrm{~m}$ thick on melting of the containing ice. Where the top surface of buried ice masses lies above the maximum depth of summer thaw, hitherto englacial debris is released as till at this surface. Production of till will presumably continue until its increasing thickness 
is equal to the maximum depth of summer thawing. If this overburden remains stable, the underlying glacier ice will not resume melting until the climate changes in such a way as to increase the depth of summer thawing.

In many cases, however, the released material tends to move down-slope, presumably changing any structure which may have been preserved from the parent ice. If, however, it melts out into a stable situation beneath sufficient overburden to inhibit deformation under gravity, the till preserves structures derived from the parent ice, and for this the term "melt-out till"' is suggested.

In Svalbard, maximum depths of summer thawing are small, being rarely greater than I-2 $\mathrm{m}$ depending on aspect, soil type, presence of surface water bodies, etc. Thus in many areas melt-out till only forms at the top surface of buried ice masses which lie at shallow depth. However, sediment-filled lakes and streams commonly occur above stagnant ice masses, and their relatively high thermal capacities can induce melting of ice even at considerable depth

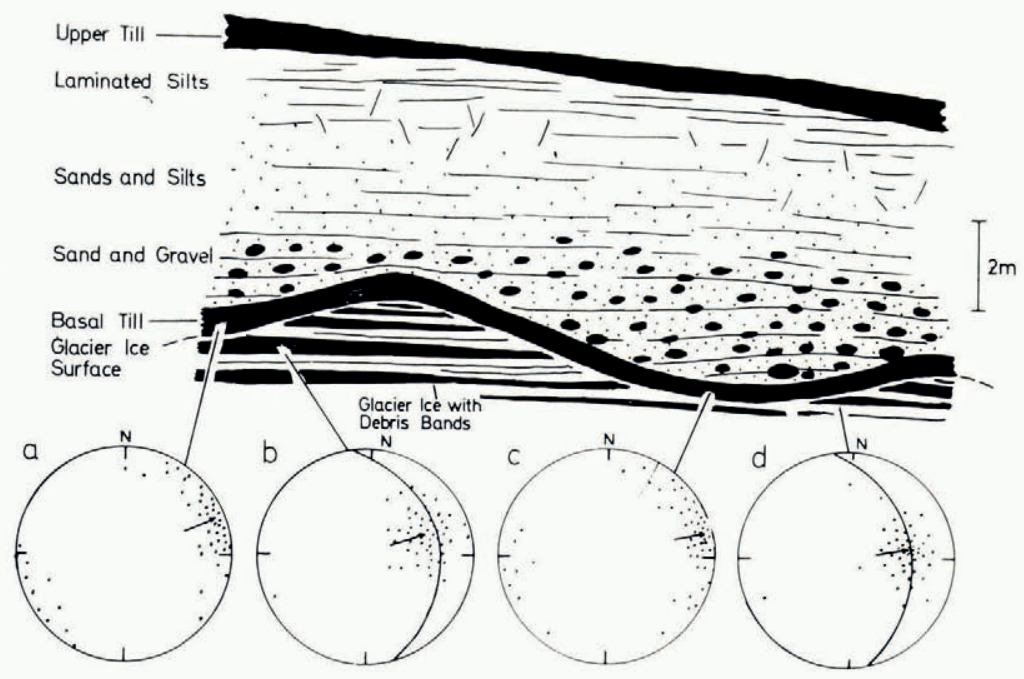

Fig. 2. A supraglacial section at the margin of Erikabreen in Oscar II Land. $(a),(b),(c)$ and (d) are equal-area stereographic plots of long axes of blade-shaped stones (5o measurements in each case). (a) and $(c)$ are of stones from the lower till, and $(b)$ and $(d)$ are of englacial stones. In $(b)$ and $(d)$ cyclographic traces show the dip of the glacier-ice foliation, which is approximately parallel to present-day glacier movement. The arrows show the direction of the computed mean vector.

beneath their sediment-covered beds. Figure 2 shows a downward sequence of upper till, laminated silts and sands, sand and gravel, and lower till, all of which rest on debris-rich glacier ice at the margin of Erikabreen in Oscar II Land. The whole sequence was frozen to within $2 \mathrm{~m}$ of the surface in early August. There is good evidence to show that the laminated silts and sands were laid down in a pro-glacial lake into which, at a later stage, the overlying till flowed, and the gravels presumably represent supraglacial fluvial activity before the lake formed. The glacier-ice surface is irregular but the overlying lower till maintains an almost uniform thickness of about $0.4 \mathrm{~m}$. If this till were a flow till, its maximum thickness would tend to be distributed at the low points of the ice surface. Also, had the gravels been deposited directly upon this till, the high-velocity depositing current would have tended to scour into this pre-existing silt-clay till, but of this there is no sign. It is therefore suggested that the gravels were deposited directly on to an ice surface and that the till was subsequently released at this interface by melting, because of the existence of a supraglacial lake of relatively high 
thermal capacity. The freezing of the sediment column then occurred after the disappearance of the lake.

The till is grey-black, rich in clay and silt, and contains boulders up to $0.3 \mathrm{~m}$ in diameter and numerous parallel ice layers up to $5 \mathrm{~mm}$ in thickness. The orientation of till stones between 5 and $20 \mathrm{~cm}$ in diameter was measured at two localities within the till and they are plotted stereographically in Figure 2. (The common occurrence of blade-shaped stones with an axial ratio of approximately $3: 2:$ I made it possible to use these alone.) The glacier ice beneath the till contains a high proportion of suspended debris which is segregated into pronounced bands dipping towards the glacier at $20-25^{\circ}$. Long axes of stones similar to those from the till were measured at two localities in this ice and they are plotted stereographically in Figure 2.

The stereograms show a consistency of orientation between the two sites within the till, and between the two sites within the underlying ice (if an adjustment is made for foliation dip direction). Although preferred orientations of long axes in the ice and till are similar in azimuth, those in the till show a greater dispersion, and the inclination of long axes is much less in the till than in the ice. Statistical analysis employing Fisher's distribution (Steinmetz, 1962) was used to determine the direction of the mean vector and the radii of circles of confidence (Fig. 2). Analysis also shows that samples (a) and (d) are drawn from the same population and that (c) and (d) are drawn from another population; the hypothesis that these two populations are the same is rejected at the $99 \%$ significance level.

Assuming that when the till stones were englacial they had similar orientations to the stones now found in the ice, release of this till from the ice has had two effects:

(a) The $a-b$ planes of stones were originally largely parallel to the ice foliation, but ice melting has lessened vertical distances so that $a-b$ planes now tend to lie in the horizontal plane.

(b) The strength of orientation has been weakened. This might well result from the interaction of stones which were originally separated by ice. Melting of the ice has now brought them into contact, and mutual disturbance has weakened the original orientation strength.

No assessment of possible disturbance of micro-fabric elements as a result of melting was possible but it is likely that this could be considerable.

\section{The effect of climatic amelioration}

Although there is only a limited amount of top melting of buried stagnant ice in presentday Svalbard, and many such ice masses are semi-permanent, it is important to assess the effect of climatic amelioration on the melting of these ice masses. In the cold outer zones of Svalbard glaciers there is an upward temperature gradient from the pressure melting point or just below at the glacier sole to temperatures of the order of $-8^{\circ}$ to $-10^{\circ} \mathrm{C}$ at depths of about 5 to $10 \mathrm{~m}$ below the glacier surface (average depths of seasonal variation). Geothermal heat is thus conducted upwards through the glacier and, except in those areas where the glacier has recently advanced, there is only a very limited extension of permafrost beneath its margin. When large masses of glacier ice become stagnant during retreat, the heat flow through these masses changes because of their immobility. Heat is dissipated and the $0^{\circ} \mathrm{C}$ isotherm is pushed well below the original glacier sole, the glacier ice effectively becoming the topmost layer of the permafrost.

If the climate begins to ameliorate by way of an increase in mean annual temperature, the depth of the active layer will increase and the base of the permafrost will slowly rise, there being a downward temperature gradient due to surface warming and an upward gradient due to the geothermal heat flux. The relative importance of these processes of top and bottom melting, and whether basal melting of the permafrost reaches the base of the dead glacier ice before the latter is destroyed by surface melting, depend upon many variables: the initial depth of 
permafrost, the rate of climatic amelioration, the thickness of the dead glacier ice, etc. The ability of geothermal heat to produce bottom melting depends to a large extent on the amount of heat supplied at the surface; if this increases, the rate of bottom melting will increase and vice versa. However, top melting is likely to be a much more rapid process than bottom melting as the geothermal heat flux has an average value of only $167 \mathrm{~J} \mathrm{~cm}^{-2}$ year-1 and, although there are situations in which the latter could be important, top melting is likely to be of much greater importance. This conclusion runs contrary to that of Carruthers (1953), who inferred from ancient glacial deposits that "under melting" of dead glacier ice was of paramount importance in the genesis of basal till.

The effect of top melting. The elements of englacial structure retained by a till released at the top surface of a buried ice mass depend upon the melting-out process, and the position into which the till is released. Melting of interstitial ice changes stone fabrics by bringing hitherto separated particles into contact, and the dip of inclined features is reduced. This not only applies to the inclination of till stones but to the inclination of the limbs of any folds derived from the parent glacier ice. The position into which a till is released is also important. Debris released as till at the top surface of a buried ice mass will retain elements of its englacial structure, if there is an opportunity for melt water to escape from it laterally and if the overburden is thick enough and the surface slope low enough to ensure that lateral flow or creep do not occur. If melt water cannot escape from a till, deformation of the saturated till due to differential overburden pressure is likely to destroy any englacial structures.

The effect of bottom melting. The effect of bottom melting on englacial debris is more difficult to predict. Melting beneath a relatively thin ice overburden is referred to later. Here, at the margin of Sørbreen, it results in the collapse into small cavities of masses of debris which are then reworked by channelled subglacial melt water. Beneath a greater thickness of ice, although channels are still likely to occur, probably on a very large scale, it is conceivable that debris released by basal melting could preserve its englacial structure in areas where there is no such channelling and as long as melt water could be carried away through underlying permeable beds. If melt water cannot escape but is retained within the released till, deformation of this till under a considerable dead-ice load is likely to destroy its englacial structures.

Tills produced either by top or bottom melting of a block of buried debris-rich ice, and which are not deformed by subsequent creep or flow at the surface, have been referred to as melt-out tills. It is not easy to distinguish them from supraglacial flow tills, except perhaps on the basis of fabric, but it is a convenient distinction. They develop in a confined situation beneath a restraining overburden which may be flow till or ice or outwash deposits and thus, unlike flow tills, do not occur at the surface, nor do they overlie supraglacial outwash. In a glacial sequence from which the ice has disappeared, they mark the stratigraphic position of the vanished glacier.

\section{Sources of variation of melt-out till}

The englacial moraine contained in Svalbard glaciers consists of two components: material derived from nunataks or valley walls in the accumulation area and debris derived from the subglacial bed. The former tends to occur at a high level in the glacier and is of relatively small volume compared to the latter which occurs near the glacier bed.

In a previous paper (Boulton, 1970), evidence was provided to support the suggestion that much of the basally derived englacial debris is incorporated from the glacier bed by a process of basal freezing. This hypothesis makes a prediction that, if a glacier flows across a series of lithologies and if the products of erosion are included englacially by basal freezing, the downward sequence of debris types will reflect the rock types over which the glacier has moved, from distantly derived material at the top to local material near the bed. It is likely, however, that the topmost part of this sequence could contain moraine derived from the glacier surface. 
Studies by Lister $\left(\left[{ }^{\mathrm{C}} \mathrm{I} 95^{8}\right]\right)$ have indicated the possibility of another variable. Working on Admiralty Gletscher in Dronning Louise Land, Greenland, he found that the grain-size of englacial debris became gradually smaller at higher structural levels within the glacier, and on the assumption that the higher bands were furthest travelled, he suggested that there is a gradual mechanical break-down of debris transported englacially. Thus a melt-out till deposited by slow melting of buried ice might be expected to show both upward decrease in grain-size (assuming a constant source material) and lateral decrease in grain-size at any level in the direction of ice movement.

It should be borne in mind, however, that numerous complications could affect this system: thrusting, basal ice stagnation, etc.

\section{DEPOSITION OF SUBGLAGial TILLS FROM ACTIVE ICE}

Till can only be deposited from active ice in a subglacial position, a glacier zone which is rarely seen and difficult of access. Observations of the glacier/bedrock contact were made at eight localities on five glaciers, but a substantial thickness of till or potential till between glacier and bedrock was only observed at three of these localities. Some of these observations of subglacial till on the glaciers Sørbreen and Nordenskiöldbreen are presented below. It will be suggested that these tills are the product of melting of masses of debris-rich ice which have become stagnant beneath the active glacier.

\section{Sorbreen}

This is a narrow valley glacier which drains part of the Ny Friesland highland ice to the west, and which has a bi-lobed terminus. The northern lobe flows out onto a flat outwash plain and is stagnant at its frontal margin. Compression at this margin causes englacial debris bands to incline upwards and crop out on the low-angle glacier surface, giving rise to a complex supraglacial moraine (Boulton, i968).

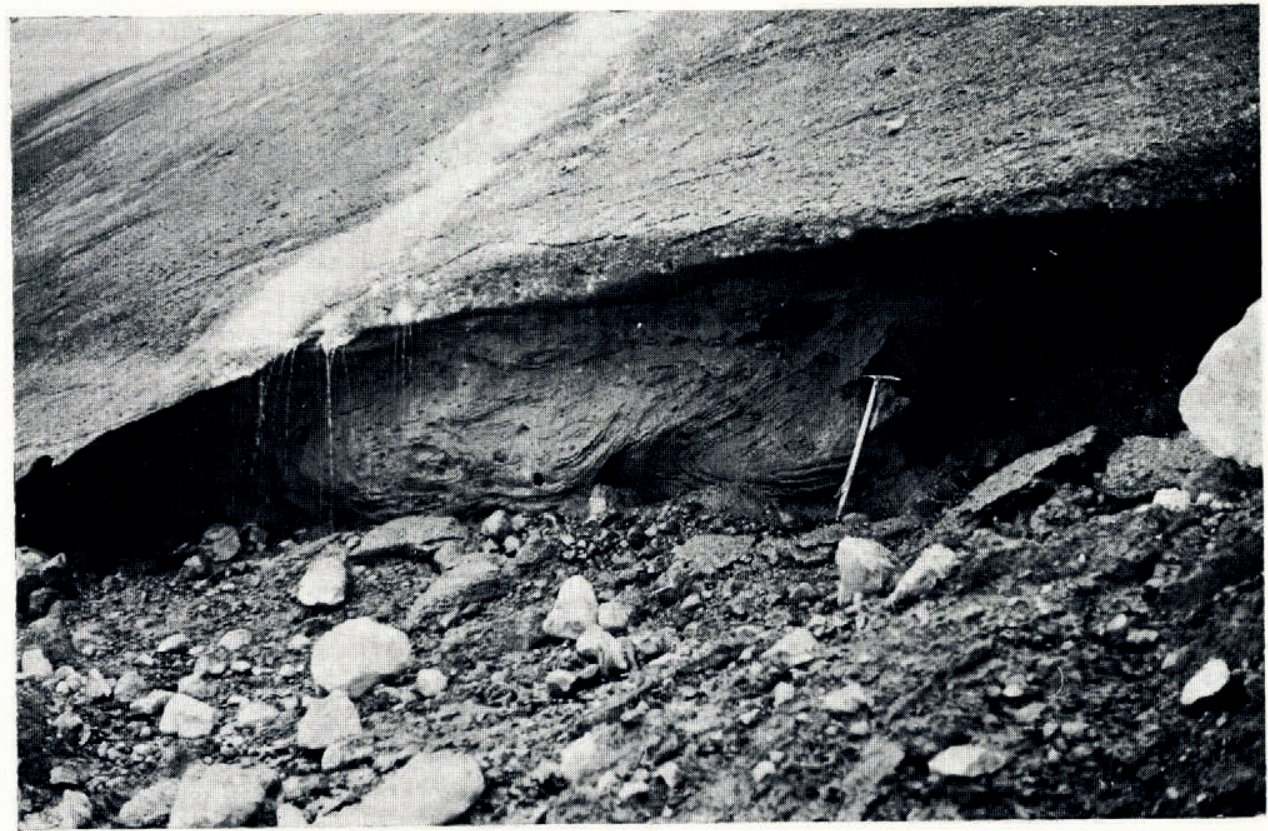

Fig. 3. Highly folded, debris-rich stagnant ice over-ridden along a thrust plane by active ice, which contains little debris, in the southern lobe of Sorbreen. Note the rotten nature of the basal stagnant ice and the facets ground on many of the boulders derived from this ice. 
The situation at the margin of the southern lobe is however entirely different. Here the glacier has a steep front and is flowing down the western flank of a bedrock step, the glacier thus being in a state of longitudinal tension. As a result, few debris bands incline upwards towards the glacier surface, the majority occurring immediately above the glacier bed. At several points along the frontal margin of the glacier, basal debris-rich ice is revealed beneath a sharp contact with overlying active ice in which there is a relatively small amount of debris (Fig. 3). The debris content of this basal stagnant ice, which does not extend more than $2 \mathrm{~m}$ above bedrock, is in some places concentrated into well-defined bands with high concentrations (up to $40 \%$ ) of dominantly silt-sized rock flour. At one locality there is a lateral transition from stagnant ice with well-marked debris bands to frozen subglacial till which still retains a banded appearance. In some places, as shown in Figure 3, relatively coarse-grained debris with boulders up to $\mathrm{I} \mathrm{m}$ in diameter, many of which have flattened facets bearing striations, is disseminated throughout the subglacial stagnant ice with little separation into debris bands and ice layers. The foliation of the basal debris-rich ice is thrown into a series of overturned folds which are cut off by the sharp planar contact with the overlying clean ice. The strike of the axial planes of these folds trends at right-angles to the direction of glacier movement. Slickensides are commonly developed along the shear plane separating stagnant debris-rich ice from the over-riding glacier sole above. The stagnant ice may be in the process of being actively deformed by the over-riding glacier but some parts, especially those with a high debris content, are probably quite stationary. It is noticeable that the percentage of debris contained within the stagnant ice masses is generally much greater than is found in active ice, suggesting that ice may have been expelled from them.

In several places just under the active glacier sole, melting of the stagnant ice mass is taking place. The process appears to be very irregular, producing small cavities beneath the ice into which debris is falling, and in places small rivulets are transporting this fallen debris.

\section{Nordenskiöldbreen}

Beneath this active glacier there occur large masses of stagnant debris-rich ice, similar to those noted on Sørbreen, but many are at a more advanced stage, tills having completely or partially melted out from them. These thick tills are similar to many of the fine-grained, overconsolidated Pleistocene tills of lowland areas of Europe and North America, and are important in that they are one of the very few unequivocally subglacial tills to be described from Svalbard, or any modern polar glacier.

Nordenskiöldbreen is situated in Bunsowland and drains part of Lomonosovfonna (an area of highland ice) in a westerly direction (Fig. 4a). It has several prominent nunataks along its central line and in its lowermost $7 \mathrm{~km}$ it flows between steep rock walls, terminating in an ice cliff in Adolfbukta at the head of Billefjorden. The glacier has a relatively steep terminal gradient of $7^{\circ}$ and the firn line is situated at $640 \mathrm{~m}$ above sea-level; temperature measurements by Zinger and others ( 1966 ) show it is a cold glacier. It has a record of almost continuous though slow retreat since r 898 .

Figure $4 \mathrm{~b}$ is a map of the northern part of the glacier front where it abuts against the northern shore of Adolfbukta. The bedrock in the pro-glacial area consists of Hecla Hoek schists and gneisses which have been deeply eroded by the glacier to give an undulating roche moutonnée surface. Striae give a clear picture of local glacier movement, which appears to be largely controlled by the undulating bedrock topography. Although striae vary considerably over small areas, depending on the local bedrock slope, there is a regional pattern which indicates that the direction of ice movement lies between $220^{\circ}$ and $255^{\circ}$. The roche moutonnée surface is partially submerged by fluvial deposits and tills which lie in the hollows between hummocks and at the margins of stream channels. The fluvial deposits have been laid down by a series of ice-marginal streams which have migrated in an easterly direction as the ice front has retreated, and are often underlain by relatively small blocks of dead ice (Fig. 4c and d). 
The stream which runs along the present ice margin cuts into and beneath the glacier in several places, and just before it reaches the fjord exposes several fine ice-cliff sections and sections in subglacial stream tunnels. The way in which till can be released basally from glacier ice is well illustrated in this series of sections. From K to L (Fig. 4c) an unfrozen till is exposed, resting on bedrock and immediately overlain by fluvial deposits, but from $\mathrm{L}$ to $\mathrm{M}$ the same till is englacial and subglacial, and in the process of being released from the ice (Fig. 4d).

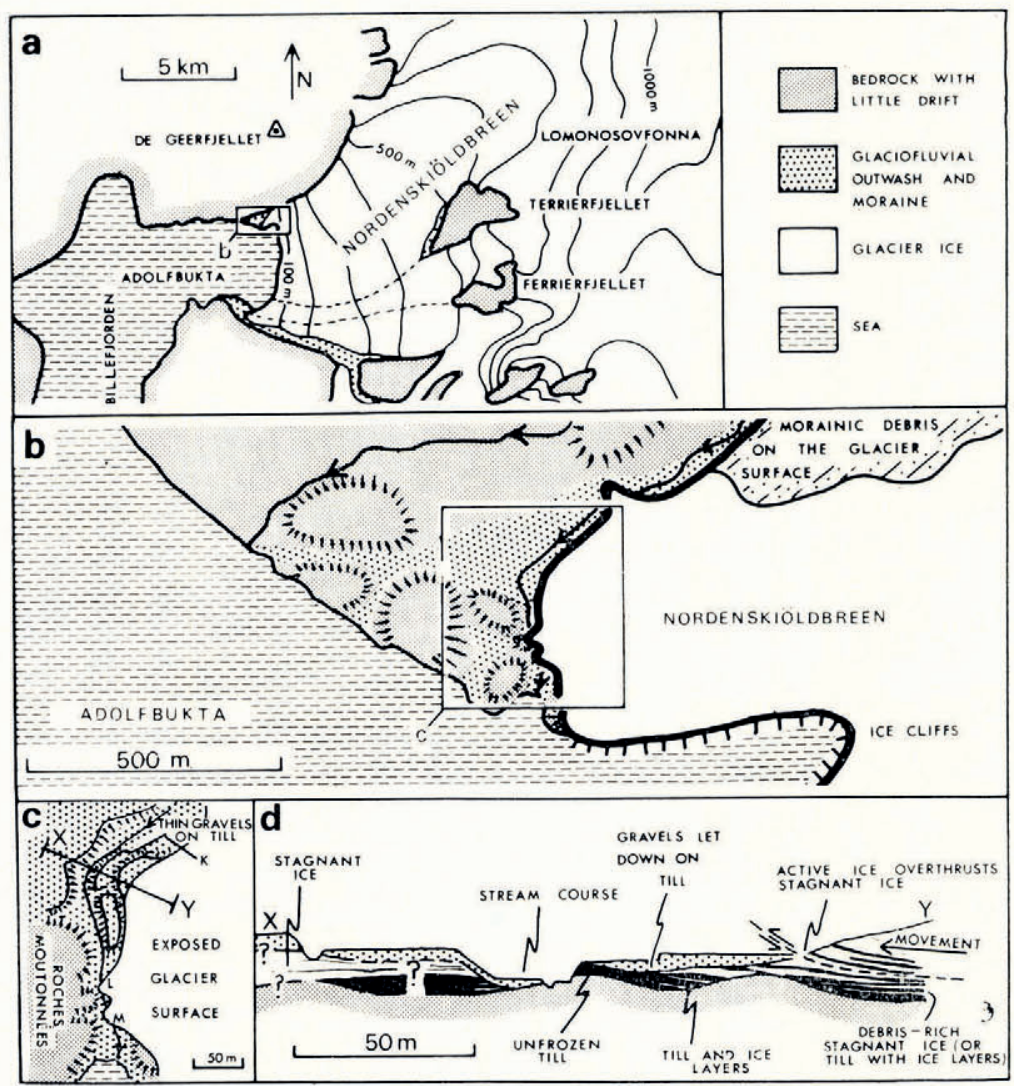

Fig. 4. a. Map showing the position of .Nordenskiöldbreen at the head of Billefjorden.

$b$. Part of the northern margin of Nordenskiöldbreen.
c. Detail of part of the northern margin, showing the glacier margin resting on a roche moutonnée surface and partly overlain by fluvial deposits.

d. Section along the line $X-Y$ in $(c)$. Debris-rich stagnant ice lies beneath the active glacier and beneath supraglacial fluvial deposits. Note the way in which originally supraglacial gravels have been let down on to basal till by melting of the intervening ice.

Figure 5 is a general view of an exposure of subglacial till at $\mathrm{M}$ (Fig. 4c). A maximum of $2.4 \mathrm{~m}$ of till is exposed beneath a prominent roof of relatively clean active ice, which rests on the side of the roche moutonnée to the left. The till is brown (grey on drying out), silt and clayrich, and contains angular boulders of dark mica-schists and granitoid rocks (up to $20 \mathrm{~cm}$ in diameter) mostly of local origin. Comminuted shell fragments occur within the upper I. $8 \mathrm{~m}$ but in the lowermost $0.6 \mathrm{~m}$ abundant well-preserved shells occur, some of which, even the most delicate, are still articulated although the ligaments have rotted away. Some 
streaked-out plant debris is also found in the basal $30 \mathrm{~cm}$. The contact between the active glacier sole and the underlying till carries well-marked slickensides trending north and the till itself is jointed in a complex fashion (Figs. 6 and 7). The most prominent are a series of sub-horizontal joints which split the till up into a number of elongate lenses which vary in thickness from about 5 to $30 \mathrm{~cm}$. Some of the sub-horizontal joint surfaces bear faint slickensides reflecting the changing direction of glacier over-riding, and indicate that the joints have acted as brittle displacement shears, and the intervening till lenses as tectonic shear lenses. The lenses themselves, though massive and unfoliated, are cut by three sets of joints, one set normal to the direction of glacier over-riding represented by slickensides on adjacent displacement shears and which vary in dip from vertical to $20^{\circ}$ up-glacier, and a conjugate pair which vary from $70^{\circ}$ to vertical in inclination and trend to $65^{\circ}$ on either side of the direction of glacier over-riding. Slickensides trend from $360^{\circ}$ to $060^{\circ}$ in the topmost metre of the till, and

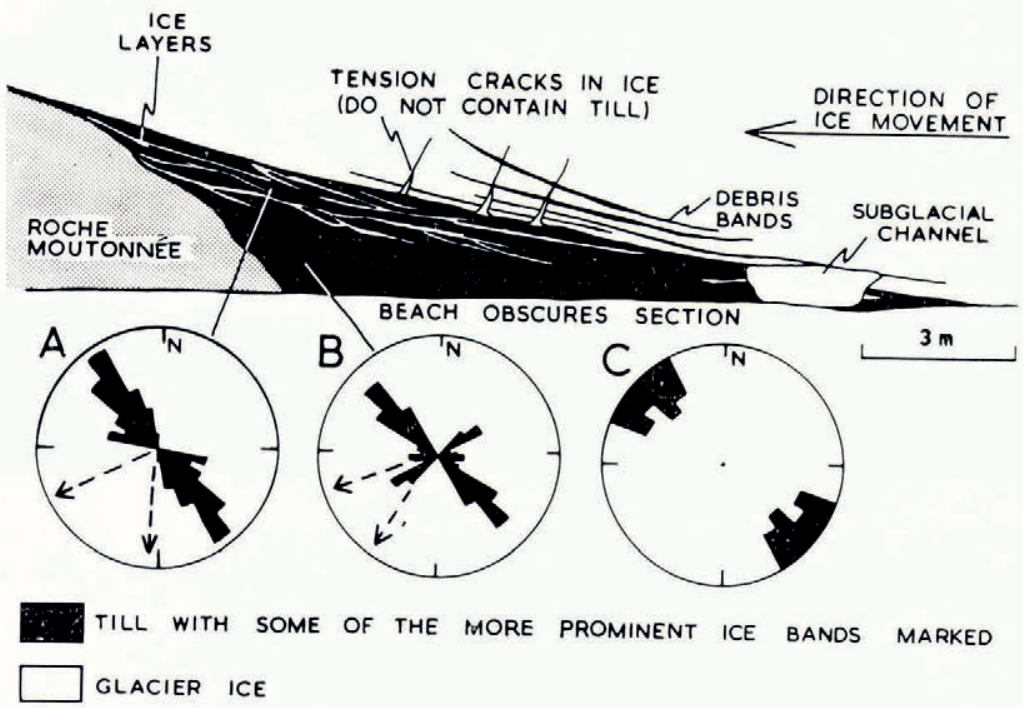

Fig. 5. Section at locality $M$ (Fig. 4c). Active glacier ice over-rides partly frozen till banked against the flank of a roche moutonnée. Note the ice layers lying along shear planes within the till. A and B are rose diagrams showing the orientations of long axes of rod-and blade-shaped till stones, projected on to the horizontal plane. 7o measurements at $A$ and 68 at $B$. Dashed arrows show the variation in direction of slickensides on sub-horizontal shear planes at these two horizons, reflecting the direction of glacier over-riding. C shows the orientation of 24 high-angle joints measured throughout the till.

from $030^{\circ}$ to $070^{\circ}$ at lower levels. Apart from the basal $30 \mathrm{~cm}$, the till is frozen, containing $5 \%$ of ice. In the topmost $0.7 \mathrm{~m}$, ice layers up to $6 \mathrm{~cm}$ thick occur along displacement shears and are commonly cut by other shear planes. The ice layers contain debris particles, in many cases their interfaces with till being slickensided. In places, non-matching slickensides occur on upper and lower surfaces of joints, suggesting that the slickensides formed against an intermediate ice layer which has since melted. Thinner, clean ice layers which are not cut by shear planes and which carry no slickensides also occur along displacement shears throughout the frozen till.

The orientations of large boulders were measured at two horizons within this till (Fig. 5, $\mathrm{A}$ and $\mathrm{B}$ ) and show strong orientations transverse to glacier flow, although $\mathrm{B}$ has a minor parallel peak.

The till exposed at M (Fig. 4c) can be traced easily under the ice along the channel of the subglacial stream, where it passes laterally into a complex ice/debris/till mass (Fig. 4d) which 


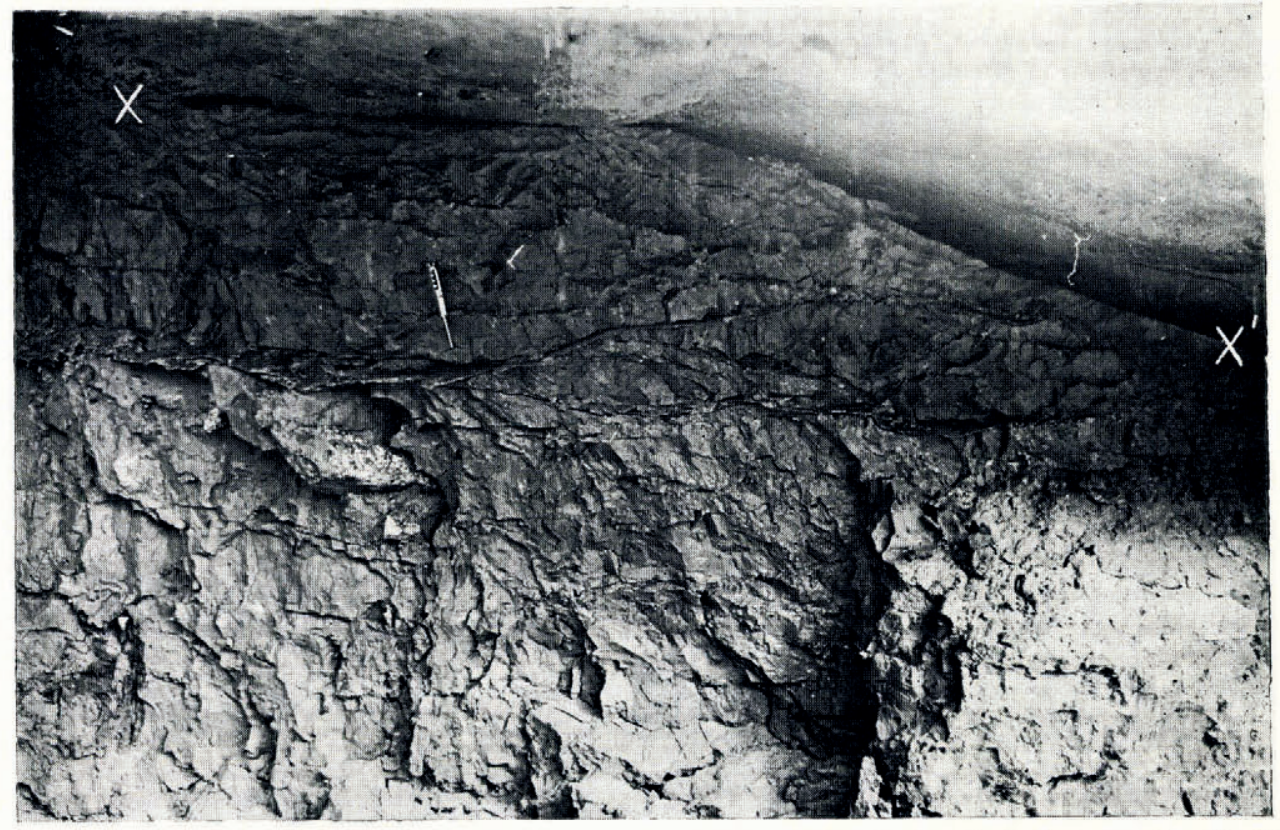

Fig. 6. Photograph of till at locality $M$ (Fig. 4c), showing the over-riding glacier ice $\left(x-x^{\prime}\right)$ the bottom surface of which is striated, and prominent ice bands and sub-horizontal joints cutting the till into a series of lenses. Thickness of till shown in this photograph is $1.3 \mathrm{~m}$.

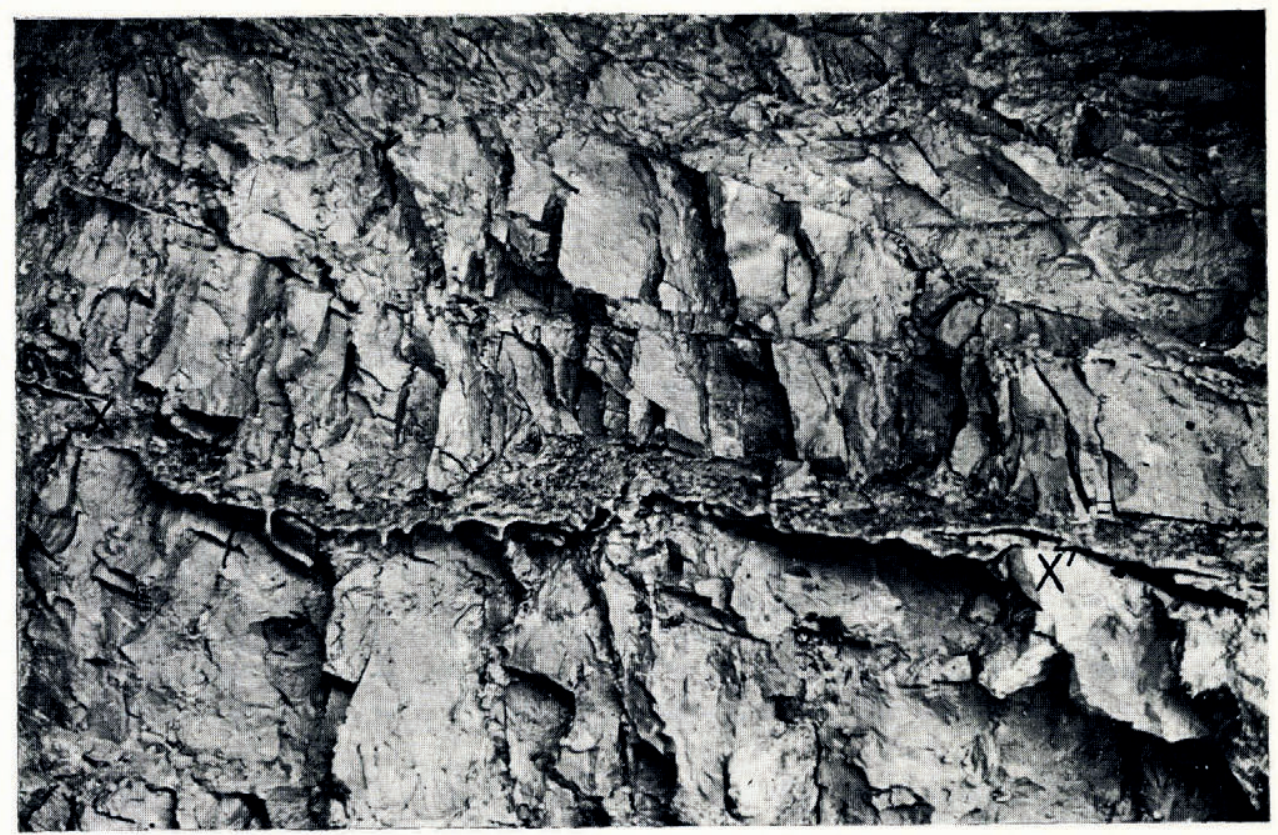

Fig. 7. Detail of till at locality $\mathcal{N}$. Sub-horizontal planes cut the till into a series of tectonic shear lenses, which are themselves cut by high-angle joints roughly transverse to glacier movement (Fig. 5). The till between the major joints is massive, not showing visible foliation. Note the prominent ice layer $\left(x-x^{\prime}\right)$ which lies along a shear plane. Thickness of till in this photograph is $0.4 \mathrm{~m}$. 
is also overlain by the relatively clean slickensided surface of active ice. This active ice surface rests on the summits of roches moutonnées and only in the hollows between these do considerable thicknesses of the subglacial masses occur (a maximum of $4 \mathrm{~m}$ was noted).

The active ice contains debris bands up to $0.4 \mathrm{~m}$ thick consisting of sandy silt with some pebbles and comminuted marine shell fragments, and with an ice content rarely less than $60 \%$ by volume. The subglacial till/ice masses display a consistent sequence. The uppermost part consists of glacier-ice layers up to $0.5 \mathrm{~m}$ thick, with intervening bands of debris similar to the bands in the active ice (both contain comminuted shells) except that they have a much lower ice content (up to $30 \%$ by volume). This part grades downwards with decreasing ice content into frozen till with a few ice layers and lenses (similar to the till shown in Figure 6) consisting of the same material as the debris bands. Beneath this in some places there occurs till containing unbroken marine shells. (The section at locality $M$ only shows the lowest two of these three units.)

A subglacial till from which all the ice has melted is exposed in the subaerial stream section between $\mathrm{K}$ and L (Fig. 4c), where it underlies up to I $\mathrm{m}$ of fluvial gravels. In some places the till/gravel contact is a planar conformable one but in others it is highly irregular. Much of the sand and gravel which lies upon the till was not deposited in that position but appears to have been deposited supraglacially and subsequently let down on to the subglacial till by melting of the intervening ice (Fig. 4d). In such cases the till/gravel contact is sometimes planar, sometimes irregular, but always sharp. Sands and gravels, which were fluvially deposited directly on till rather than supraglacially, tend to contain much material derived from the till, the contact between till and stratified sediment thus being gradational. The area lying to the west of the stream consists of a series of flat-topped kame-like sand and gravel mounds, obviously laid down by previous ice-marginal streams, and it is underlain by glacier ice which often overlies a basal ice/till mass (Fig. 4d).

The unfrozen basal till which crops out in the banks of the stream between $\mathrm{K}$ and $\mathrm{L}$ shows a clear pattern of jointing, similar to that noted at locality $M$ but on a much finer scale. The complex of joints on a small block of till are plotted in Figure 8. This till appears to be much more highly sheared than that at $\mathrm{M}$; the dominant structures are still slickensided displacement shears but between them there are a complex series of thrust shears between which the till itself is highly foliated. Thin sections made across the slickensided surfaces show a concentration along them of strongly orientated clay particles. Although few actual measurements were made, the orientation maximum of long axes of small stones within this till appears to lie parallel to the inferred direction of glacier movement rather than transverse as at $\mathrm{M}$, suggesting that an original transverse orientation has been converted to a parallel one due to the reorientation of stones which are intersected by shear planes.

The till generally rests on smoothed and striated bedrock but in one place it is seen resting on sands. The contact between till and sand is not easy to pinpoint, much clay and silt from the till lying within the sand. The bedding in the sand is difficult to determine but a wispy, isoclinally folded bedding was just discernible dipping up-glacier at about $\mathrm{IO}^{\circ}$.

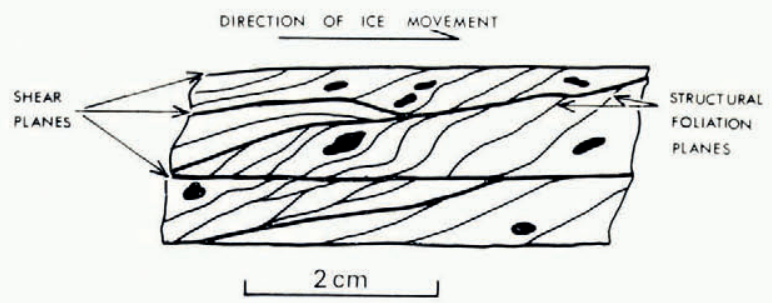

Fig. 8. Side view of a small block of till. The thick lines represent major shear planes which carry faint slickensides parallel to ice movement. The thinner lines mark major foliation planes, although the whole of the till is finely foliated. 


\section{Discussion}

The till at locality M (Fig. 5) is part of a large discontinuous till/ice complex separated from overlying active ice by a prominent shear plane. In this complex there is a lateral and vertical transition from frozen till to ice which contains debris bands similar to those in the overlying active ice. It is suggested that the ice containing debris bands was originally active ice which has become stagnant beneath the active glacier, and that the till into which it passes is a similar deposit from which the ice has largely melted.

The upper part of the subglacial masses often consists of glacier ice with debris bands which have obviously not undergone melting. The frozen till which occurs beneath this level appears to have been derived by melting from the above debris-rich ice. The lowest unit of these till/ice masses is of sporadic occurrence and contains whole though fragile shells. These cannot have been subjected to the englacial shearing which has produced shell comminution in the debris bands in the active ice and in their derivatives, the low ice-content debris bands and the tills of the subglacial till/ice masses. Neither is it likely that fragile shells could have survived if the till had been sheared beneath the glacier sole. Unbroken shells might be explained if the till was originally a marine deposit lying on the fjord bottom (deposited either as a marine flow till (cf. Boulton, 1968, p. 403) or as a marine mud containing stones dropped by icebergs) which has been frozen en masse into the glacier. Such a bed of marine deposits in the lowest part of an englacial debris sequence has been described from Aavatsmarkbreen (Boulton, 1970), which moves over a small marine bay before moving over land. If this sequence were to become stagnant beneath the active glacier, melting would produce a subglacial till such as that of Nordenskiöldbreen, in which the lowermost part is marine in origin.

There are two possible origins for the ice layers within the till at locality $\mathrm{N}$ : they could be remanié layers of glacier ice or ice layers resulting from refreezing of the till. The ice layers which are cut by and therefore pre-date the shear planes contain debris, which is uncharacteristic of segregation ice, and must therefore be remanié layers of glacier ice. The series of ice layers which contain no debris are not displaced by shear planes and therefore post-date them. These ice layers thus cannot be glacier-ice layers and must be segregation-ice layers indicating refreezing of the till. Thus it seems likely that, after the initial stagnation of debris-rich ice beneath the glacier, basal melting reduced the ice content of the lower part of this mass to such an extent that the over-riding of the glacier induced brittle fracture in those parts which had thawed to give a till. The low-angle shear planes and high-angle transverse and conjugate joints were formed during this phase. Indeed, the fact that the delicate marine shells survived this phase of shearing suggests that the response to glacier over-riding was predominantly in the formation of brittle fractures rather than in intergranular flow. Thus it is likely that the transverse stone-orientation fabrics shown in Figure 5 ante-date the phase of shearing, originating probably from the period when this till was a series of debris bands in actively flowing glacier ice. However, where stones are intercepted by shear planes, re-orientation of long axes parallel to shear takes place, and where shear planes are close together (as in Figure 8) a major orientation peak parallel to flow occurs.

The striations on the undulating bedrock surface in the pro-glacial area of Nordenskiöldbreen show the way in which the plastic basal layers of the glacier flow-directions varying considerably from the general line of advance of the glacier. Thus the fabrics of tills transported in these basal layers will reflect local directions of movement rather than a regional trend and, in order to determine the direction of glacier advance, it is necessary to plot the regional pattern of till-fabric orientations. Not only does the direction of glacier advance vary from place to place but it changes with time within one site. This is indicated in the till at locality M (Fig. 5) by the gradual upward change in the stone-orientation fabrics, by the slickensides on sub-horizontal till joints and the slickensides on the till/ice interface.

From the arguments presented above, the following history for the subglacial tills of Nordenskiöldbreen is suggested: 
I. The basal part of the active glacier contained a series of bands of disseminated debris, similar to those currently found in the active ice. These were probably formed by the grain-by-grain incorporation of the products of erosion by some mechanism of basal freezing. Stone-orientation fabrics with a transverse peak then developed within these debris bands during compressive flow of the glacier over bedrock obstacles. Beneath this level there was a layer of closely packed debris which had been frozen into the glacier en masse as the glacier moved over marine till on the fjord bottom, and which was then transported by the glacier as a unit.

2. Bedrock obstacles, over which the rate of glacier flow increased, caused the basal debris-rich less plastic ice to be over-ridden by the higher more plastic relatively debris-free ice. Thus masses of subglacial debris-rich ice formed on the flanks of bedrock obstructions. The geothermal heat-flux led to melting of these subglacial masses from the bottom upwards, producing an unfrozen subglacial till. However, in many places melting did not extend upwards throughout the whole thickness of the subglacial masses, so that till graded up into debris-rich ice. The rate of bottom melting of the debris-rich masses, assuming an average geothermal heat-flux of $167 \mathrm{~J} \mathrm{~cm}^{2}$ year ${ }^{-1}$, would be about $\mathrm{I} \mathrm{cm}_{\text {year }}-1$ for ice with a $50 \%$ debris content. Thus basal melting is a very slow process, although the heat produced by glacier sliding would increase the rate of melting.

3. Melt water was gradually expelled from the thawing till by the pressure of the overriding ice, the till thus becoming more compact.

4. As the degree of compaction increased, brittle fracture took place in the till in the form of low-angle shear planes together with high-angle transverse joints, splitting the till into a series of tectonic "shear lenses". There was little intergranular flow within the till and thus no re-orientation of the transverse-orientated stones, except where they were intercepted by shear planes and re-orientated into a direction parallel to glacier movement.

5. As the glacier retreated and the thickness of overlying active ice decreased brittle fracture ceased. The till was exposed to cooling near the glacier margin and those parts which had thawed refroze, and segregation-ice layers formed.

Evidence has been presented both from Sørbreen and Nordenskiöldbreen that debris-rich ice can become stagnant beneath an active glacier sole. Of the several possible mechanisms which could cause this stagnation, the following are suggested as the most likely: (a) Stagnant debris-rich ice may build up on the up-glacier side of an obstacle simply because of the obstruction of the latter to flow. The obstacle causes an increase in the rate of flow of the over-riding glacier and, as the overlying clean ice is capable of a much greater rate of strain than the debris-rich ice, it over-rides the latter which then becomes stagnant. (b) The decrease in plasticity of the basal debris-rich ice under a smaller ice overburden as it moves towards the glacier margin could give rise to its stagnation beneath clean active ice.

\section{A possible origin for certain types of drumlin}

The mechanism suggested above, in which stagnant debris-rich ice is released beneath an active glacier sole, might account for the formation of certain drumlins. Debris-rich stagnant ice could be deposited around the flanks of a subglacial obstruction as a result of local increase in the rate of shear as the glacier passes over the obstruction. On melting, a rock-cored drumlin might result. The till banked up on the up-glacier side of the roche moutonnée in Figure 5 forms the up-glacier flank of such a drumlin. The obstruction to flow necessary to precipitate basal masses of stagnant ice could also be provided where bedrock obstructions do not occur, by the local subglacial occurrences of coarser-grained materials with a greater shear strength than the surrounding sediments, in the manner proposed by Smalley and Unwin (ig68). 


\section{The nature of the glacier/bedrock contact in Svalbard}

The above observations of subglacial till are relatively rare. The glacier/bedrock interface was seen at six other localities in four glaciers, and in five of these localities the glacier sole lay directly on smoothed and striated bedrock. In the other locality a lens of till $5 \mathrm{~m}$ long and $30 \mathrm{~cm}$ thick occurred at the otherwise direct contact between glacier sole and bedrock. Gripp (1929), who investigated the marginal zones of 21 Spitsbergen glaciers, observed no subglacial till and wrote that "Wo wir das Liegende des Gletschers einwandfrei vor uns sahen, lag Eis auf anstehenden Gestein".

However, Klimaczewski (i 960 ) recorded a "bottom moraine" 2-3 $\mathrm{m}$ thick with "gneiss structure" and "thin (about $3 \mathrm{~cm}$ ) strata and lenses of pure ice", a description which fits well with that of the subglacial till on Nordenskiöldbreen. Other observations of Klimaczewski were of a direct glacier sole/bedrock contact, in which the foliation of the Hecla Hoek bedrock is deformed by glacier over-riding.

Although the number of recorded observations of the glacier/bedrock contact in Spitsbergen is few (between $I_{5}$ and 20), there appears to be a general absence of till at this contact. This could well be a measure of the efficacy of the process (basal freezing) by which products of subglacial erosion and pre-existing subglacial sediments are lifted into an englacial position in the marginal zones of glaciers.

The subglacial tills discussed here are derived from an englacial position rather than produced entirely subglacially. It is important to note that their response to ice loading and shear is water expulsion, compaction and brittle fracture rather than fluid flow to zones of lower pressure, giving rise to the "gneiss structure" described by Klimaczewski.

It has been suggested by Hoppe (1952) that highly fluid subglacial tills are likely to be of common occurrence. It is conceivable that, if subglacial till lies in a closed system in which water is made available but unable to escape, subglacial pore pressures will build up and the till will become fluid. Such a system would exist if the subglacial bedrock were impermeable and the subglacial topography irregular in such a way as to form enclosed basins. It could also exist if outward flow of subglacial water were blocked by permafrost beneath the outer part of the glacier. It is suggested, however, that enclosed basins are relatively rare in areas from which glaciers have retreated and that, although permafrost might block drainage during glacier advance, it is unlikely to do so during subsequent retreat. However, this reasoning applies largely to the outer parts of glaciers, since it is difficult to predict subglacial processes in internal zones until more data are available.

It has also been suggested that the products of glacier erosion can be mechanically transported entirely subglacially. It is suggested here that only very small amounts of particulate material are likely to be transported by this mechanism at any one time, and even then frozen to the glacier sole rather than rolled along or sheared along beneath it. Subglacial shearingalong of masses of till, as proposed by some authors, seems to be unrealistic and in the special case mentioned above, where high pore pressures occur in a fine-grained subglacial accumulation, till is much more likely to move as a result of subglacial pressure differences rather than by the shearing effect of over-riding ice.

\section{Acknowledgements}

The observations in this paper were made in 1965-68 during Cambridge Spitsbergen Expeditions. Thanks are due to W. B. Harland, their director, R. H. Wallis and P. Maton, leaders, and to the Royal Society for a generous grant. Valuable discussions and criticism were contributed by J. W. Glen.

MS. received 24 January 1969 and in revised form 6 May 1969 


\section{REFERENCES} Boulton, G. S. 1968. Flow tills and related deposits on some Vestspitsbergen glaciers. Fo:trnal of Glaciology,
Vol. 7, No. 51, p. 391-412.

Boulton, G. S. 1970. On the origin and transport of englacial debris in Svalbard glaciers. Jour.ual of Glaciology, Vol. 9, No. 56, p. 213-29.

Carruthers, R. G. 1953. Glacial drifts and the undermelt theory. Newcastle upon Tyne, Harold Hill.

Gripp, K. 1929. Glaciologische und geologische Ergebnisse der Hamburgischen Spitzbergen-Expedition 1927. Naturwissenschaftlicher Verein in Hamburg. Abhandlungen aus dem Gebiet der Natureissenschaften, Bd. 22, Ht. 2-4,
p. ${ }_{146-249 .}$

Hoppe, G. 1952. Hummocky moraine regions with special reference to the interior of Norrbotten. Geografiska Annaler, Årg. 34, Ht. I-2, p. I-72.

Klimaczewski, M. 1960. Studia geomorfologiczne w zachodniej cześci Spitsbergenu miedzy Kongs-Fjorden a Eidem-Bukta. Zeszyty Naukowe Uniwersytetu Jagiellońskiego. Prace Geograficzne. Seria Nowa (Kraków), Zeszyt I.

Lister, H. [ [ ${ }^{\mathrm{c}} \mathrm{I} 95^{8}$.] The evidence of debris. (In Hamilton, R. A., ed. Venture to the Arctic. Harmondsworth, Penguin Books, p. 200-09.)

Smalley, I. J., and Unwin, D. J. I968. The formation and shape of drumlins and their distribution and orientation in drumlin fields. Fournal of Glaciology, Vol. 7, No. 51, p. 377-9o.

Steinmetz, R. ${ }^{1962 .}$. Analysis of vectorial data. Fournal of Sedimentary Petrology, Vol. 32, No. 4, p. 8o I-12.

Zinger, Ye. M., and others. 1966. Issledovaniye lednikov Shpitsbergena sovyetskoy ekspeditsiyey letom 1965 goda [Study of Spitsbergen glaciers by the Soviet expedition in the summer of $1_{96}$ ]. [By 6 authors.] Materialy Glyatsiologicheskikh Issledovaniy. Khronika. Obsuzhdeniya, 12, p. 59-72. 